\title{
TWO BOOK BILLS OF KATHERINE PARR.
}

N search of information concerning a
certain William Harper, Clerk of the
Closet to Queen Katherine Parr, I Public Record Office. Among these papers I found two bills from the King's Printer, which are worth transcribing at length. They are entirely in the exquisite handwriting of Thomas Berthelet, and in that respect differ from the longer bill presented to Henry VIII. in 1 544, now in the British Museum,' for the latter is written by a clerk, with Berthelet's receipt added to the King's warrant attached to the bill.

The date of the first of the Queen's bills is not given, but it is filed with accounts for 35 Henry VIII. and a few stray ones of the following year, and there is no reason to doubt that it belongs to that period. ${ }^{2}$ It runs as follows:

: Add. MSS. 28,196.

2 The quarterly account of the Clerk of the Closet, No. 42 or the same file, is dated 13th May, 36 Henry VIII. (1544), and it is probable that this account, beginning Ist May, is of the same year. Katherine Parr was married on i2th July, 1543. 
Delyuered to my lord of chichester ${ }^{\mathrm{r}}$ for the Quenis grace, the first day of May, vj, bokes of the psalme prayers, gorgiously boūd and gilt on the leather, at $x v{ }^{d}$ the pece Ite delyuered to the clerke of the $Q$ ueenis Closet, for her grace, ij of the said bokes of Psalme prayers, likwise gorgiously bound and gilt on the leather, at $\mathrm{xvj}^{\mathrm{d}}$ the pece Ite delyured to my lorde of Chichestre for the Quenes grace, the 4 of May, vj, of the foresayd bokes likewyse bound, and gylt on the Lether, at $\mathrm{xvj}^{\mathrm{d}}$ the pece

$$
\begin{aligned}
& \text { suña to }{ }^{\text {"s }} \text { xviij" viij" d } \\
& \text { Thomas Berthe LET. }
\end{aligned}
$$

At the top has been written by another hand 'by $M^{r}$ Bartylet,' and near the figures of the sum total is 'allor.' Close to Berthelet's signature is 'W p hurton'-that is, William Parr, Lord Parr of Horton, the Queen's uncle, who was Lord Chamberlain of her household, and therefore countersigned the account.

There can be little doubt as to the book referred to in this bill as 'Psalme prayers,' of which the Queen bought fourteen copies. Berthelet had printed in 1544 'Psalmi seu precationes,' 3 and in I 545 'Psalms or Prayers.' A copy of a later edition of the latter ( 1548 ) at the British Museum ' has this title: 'Psalmes or Prayers taken out of holye Scripture. Londini. MDxuviIr.' This is commonly known as the 'King's Prayers.' The contents

I George Day, Bishop of Chichester, 1543-51. Cooper ("Ath. Cantab.' p. 157) says he was almoner to the Queen in 1545, an office he also held under Queen Mary.

2 Augmentation Office Misc. Bk. 161. art. 46.

3 'Handlist of English Printers,' III., p. 10.

C. 51. a. 7 . 
might be better described as 'Psalms and Prayers,' as it contains the first fifteen psalms, followed by the twenty-first Psalm, and one headed ' a psalme of thankesgeuyng,' beginning, ' Reioyce and syng in the honour of the lord.' After these are two prayers, one for the King and the other 'for men to say entryng into battaile.' It is possible that there was an English edition of 1544 as well as a Latin one.

The second bill is much longer, and is clearly dated:

To the Queenes grace $a^{\circ}$ rr Ed. VI prmo.

Imprimis deliuered to master Harper for the Queenes grace, a boke of psalme praiers couered in white and gilt on the leather, price- $\mathrm{xvj}^{\mathrm{d}}$

Item a boke of the .x. conmaundements, couered in white, and gilt on the Leather, the price- $\mathrm{xij}^{\mathrm{d}}$

Item Enchiridion of Erasmus in englishe, and the boke called the preparacion to dethe, the price-

Itē delyuered to my lord of Chichester for hir grace, impris, ij praier bokes, couered in white satin, the $\mathrm{p}^{\prime} \mathrm{ce}-\mathrm{ij}^{3}$

Item .x. bokes printed in Velim of the same praiers, whiche are viijd, a pece, $\mathrm{sm}^{2} \longrightarrow \mathrm{vj}_{1}^{\mathrm{a}}$ viij ${ }^{\mathrm{d}}$

Item $\mathrm{p}^{\mathrm{d}}$ for the byndyng of .ix. of those bokes in white and gilt on the leather, for a pece, $\mathrm{vj}^{\mathrm{d}}$, the sumeiiij" vjd.

Item for. xij. of the saied praiers bound in white, and gilt on the leather, at $\mathrm{vj}^{\mathrm{d}}$ the pece sum ${ }^{2} \mathrm{vj}^{\mathrm{*}}$

Item 2 boke printed in fine velim of a great lettre the price of the same- $\mathrm{ij}^{\circ}$

Item .v. of the same bokes printed in fine velim, at $\mathrm{ij}^{\text {' the }}$ pece, the sume-_ $x^{t}$

$$
\text { sum }^{2} \text { to } 0^{\text {la }} \text { roxvi" } x^{d}
$$

IExch, Q. R. Accounts, 424. 12. 
This is not signed by Berthclet, though in his handwriting. It is allowed by Anthony Cooper, and has a note as follows:

\section{paid iiij Junij $A^{\circ} R R$ E vj pmo.}

The first item seems to be identical with the books of the previous account. The second is, no doubt, 'A Declaration of the Ten Commandments,' by Bishop Hooper, of which an edition without name of printer was published in 1548. John Byddell issued the Enchiridion of Erasmus in English, 'Cum priuiegio ad imprimendum solum,' in 1533 , $1534,153^{8}$, and 1544 , the last edition having on the colophon, 'Newly corrected and amended in the yere of oure lorde god. M V C xliiii the xix of Nouembre.' Berthelet published Erasmus' 'Preparation to Death' as early as I 543. From the above account it would seem that the two books were bound together: there are three copies of 'The Preparation to Death' of this edition of Berthelet's in the British Museum.' Two are bound up with Byddell's Enchiridion, and the third with the 'Preparation' in Latin by Berthelet.

The remaining books appear to be copies of the two editions of Katherine Parr's own 'Prayers or Meditations,' commonly called the 'Queen's Prayers,' to distinguish them from the other volume already mentioned, 'The King's Prayers.' The first edition of her book which I can find mentioned was printed by Berthelet in 1543, and others were issued in I 545, I 546, and 1547. These were all small books

I B.M. 696 a. 43 , C. 37 a. 31 , and 11982. 
in $16 \mathrm{mo}$ or $32 \mathrm{mo}$, and even when 'printed in velim' eightpence a piece would be a very probable price for them, although the idea of Berthelet bindings ' in white and gilt on the leather' at an additional sixpence may well make modern collectors sigh. Besides these tiny editions there is also an undated one in octavo, which by comparison may fairly be called ' of a great lettre'-i.e., printed in large type -and for these on vellum two shillings each would be a reasonable price. Copies of any ordinary primer or prayer-book (the first Prayer-book of Edward VI. is also ruled out of consideration by its date) would have cost as much or more than this on paper, besides not having the personal touch which accounts for the Queen purchasing so many, obviously for presentation to her friends.

Yet another bill of the Queen's is of interest to the bibliographer. It is filed with the first of these accounts of Berthelet, and is as follows:

\section{xij $^{\circ}$ April $A^{\circ}$ rr. H. viij xxxv}

Wittm Harper clerke of the closett to the queyns grace Askethe alowance as money by hym layed owt Inprmis payd for a prymar for her grace in laten and englyshe $w^{t}$ epistyles and gospeles vnbounden ij $^{\circ}$ iiij Itm for Rewlyng and Coleryng of the letteres of the seyd $\mathrm{p}^{\mathrm{r}} \mathrm{mar}$ And of her graces testement in frenche $v^{*}$ Itm payd for gyldyng coveryng and byndyng of the two seyd bokes $v^{*}$ Itm payd to the launder for washyng of the closett clothes for one quarter of the yere endyd at the Antyacon of or Lady last past $v^{5}$ Itm payd for Syngyng breades this quarter $\mathrm{xij}^{\mathrm{d}}$ Itm payd for flowers to the closett 
the $x v j$ day the xxiij" day and the $x x x^{\text {"t }}$ day of Marche vj" Itm $p^{d}$ for flowers the vj day And the xij day of Aprell iiij ${ }^{d}$

$$
\mathrm{Su}^{\mathrm{m}_{\mathrm{a}}} \mathrm{xix}^{\mathrm{di}} \mathrm{ij}^{\mathrm{d}}
$$

The Primers in Latin and English printed before this date are usually rubricated, but he may have made a copy more elaborate for the Queen's own use. Grafton, with Whitchurch, printed the Primer in Latin and English with 'Pystels and Gospels' in I 540, I 542, I 543 , and 1545 .

An effort has been made to discover what were the duties of the Clerk of the Closet at this period. As no printed account of his office has been found among the Ordinances and Regulations of the Royal Household or elsewhere, or even a description in manuscript, it is as well to put together such information on the subject as can be gleaned or inferred from the documents examined.

The position of Clerk of the Closet to the King was one of honour. In $154^{2}$ it was held by Dr. Edward Leighton, Archdeacon of Salisbury and Prebend of Westminster. ${ }^{2}$ The same official in the Queen's household was of less rank, but was also a clerk in Holy Orders. William Harper, who held the position under Katherine Parr, is probably the one of that name described by Foster ${ }^{3}$ as 'secular chaplain, fellow of New College 1 503-27, from Axbridge, Somerset, B.C.L.

${ }^{1}$ Aug. Off. Misc. Bk. 161. No. 69.

2 The Clerk of the Closet to the late King Edward was the Bishop of Ripon.

3 Alum. Oxon. 
(disp. 6 July) 1 52 1, B.Can.L. (disp. 9 Apr.) 1 522,' and who was from 1526 to 1553 Vicar of Writtle, Essex, where he was prosecuted for popish practices. We know he was the William Harper who was instituted to Sampford Courteney, Devon, i 8th October, 1 546, on the presentation of Queen Katherine Parr. It was during his incumbency of that place that the Book of Common Prayer was first used there on Whitsunday, I 549, with the result that the inhabitants of that parish on Whitmonday obliged the priest to revest himself in his 'popish attire' and read Mass; this was the beginning of the Western Rebellion in Devonshire.

As Clerk of the Queen's Closet Harper received as wages $f_{0} 6 \mathrm{I} 6 \mathrm{~s}$. I $\frac{1}{2} \mathrm{~d}$. per annum, the same sum being paid to the King's Clerk of the Closet. He sat at table with the chief officers of the Queen's household, next after the chaplains. ${ }^{I}$

Among the duties of the Clerk of the Closet appear to have been not only the care of the Closet and its appurtenances, and the supply of books, as we see above, but acting as confidential messenger and as personal attendant upon his mistress upon her journeys. There are entries of charges for half a cart at a penny a mile between different royal residences, giving the order of journeys coinciding with the Queen's movements. The cart was

- The Clerk of the Closet to Charles II. and the principal physician were the only persons under the degree of a baron or privy councillor permitted to approach the King's chair or stand under the cloth of State. ('Ordinances and Regulations of Royal Household,' p. 37 I.) This privilege had probably been granted at an earlier periad also. 
required particularly for the furniture of the Closet. ${ }^{\mathrm{x}}$ It does not appear exactly of what that furniture consisted, but on one occasion at least it was insufficient, as he asks allowance for $4 \mathrm{~d}$. 'gyven in rewarde to the clerke and sexton at buckyngham for bryngyng of theyr church stuffe to serue the quene.' On another occasion-and only this once - there is a charge for 'caryage of the plate for the closet.' Besides this there was the linen, for which he paid the 'launder' five shillings quarterly for washing, and which he describes as 'albes, awter clothes and other lynnen appertayning to the closset.' We presume there were also altar frontals and vestments of tissue or velvet with traverses and 'balkyns' or canopies, such as a King's Clerk of the Closet enumerates as pertaining to the great and the privy closet. ${ }^{2}$

He also supplied herbs and flowers as well as 'Syngyng breads.' $3 \mathrm{He}$ asks allowance for the following curious items: a perfuming panne to the closett, iiij yardes whyte caddas 4 for gyrdles, a basket lyned $w^{t}$ ledd ${ }^{r}$ to cary coles to the grett closett, a fyer sufill (elsewhere called a showyll) iiij yards of silke lace for hangyng the pycks, a skeyne of whyte thrydde, iiijc teynter hokes, a hamer, two great halfe portuas for the queyns

I If the custom followed in later reigns then obtained, the Clerk of the Closet himself would have shared the conveyance occupied by the Dean of the Chapel and the Chaplains.

- See 'Lisle Papers,' 8.

3 Explained by Halliwell as denoting sacramental wafers, but much more probably the pain benit distributed on high festivals during a sung mass.

1 Caddas $=$ worsted ribbon. See Halliwell. 
Closett, sylke laces for regesters for the portuas occupied in the quene ys closet, ${ }^{3}$ and thryd for Reparyng vestments and Removyng Albes. ${ }^{2}$

On the whole, one is led to conclude that the Clerk of the Closet was a private Chaplain who was particularly employed about the person of his master or mistress, and accompanied them upon their ordinary journeys. ${ }^{3}$

F. Rose-Troup.

1 Evidently markers.

2 This was 20th Oetober, $3^{8}$ Henry VIII., just about three months before the King's death.

3 In the Ordinances of 17 Henry VIII. arrangements are made for divine service daily " when his Grace keepeth not his haule, \& specially in rideing fourneys \& Progresses'; the master of the King's chapel, six children and six men, with some officers of the vestry, were to be continually in attendance, but no reference is made to the presence of a chaplain then. See T. R. Misc. Bk. 231, f. 46. This is quoted in 'Ordinances and Regulations of the Royal Household' (Soc. Antiq., 1790). 